Jpn. J. Spec. Educ., 41 (6), 659-669, 2004.

\title{
Review
}

\section{Qualitative Research on Inclusive Education}

\author{
Yoko ISOBE
}

\begin{abstract}
In the present article, the roles and usefulness of qualitative research in inclusive education are discussed. Considering inclusive education from a broad viewpoint, inclusion and exclusion are as much about participation and marginalisation in relation to race, class, gender, sexuality, poverty, and unemployment as they are about special education concerns about students with disabilities. Qualitative methods enabled access to human voices, perceptions, and contextbased analyses of pupils and teachers in individual schools and classrooms where inclusion is being put into practice. Future research should explore specific methods that might be used to assist children who have severe or profound disabilities, significant communication difficulties, and/or unique communication patterns.
\end{abstract}

Key Words: qualitative research, methodology, inclusive education, special education

\section{Introduction}

In the past fifteen years, educational researchers have evidenced a growing interest in alternative research methodologies (e.g., Crowley, 1994; Fosnot, 1989; Guba \& Lincoln, 1989; Heshusius, 1989). Although special education has been dominated by quantitative (e.g., surveys) and /or behavioural (e.g., single subject designs) research methods (Ferguson, Ferguson, \& Taylor, 1992), increasingly, over twenty years, one can find calls in the main professional journals of the various education-related specialties in Britain, other EU countries, and the U.S.A., for the acceptance of qualitative research (Ferguson et al., 1992; Heshusius, 1989; Jacob, 1990; Stainback \& Stainback, 1984; Taylor, 1988) and for openness to value-based inquiry (Heshusius, 1982; Skrtic, 1986; Peck, 1991). According to Peck and Furman (1992), the importance of a qualitative approach to research in special education is based on a variety of practical and philosophical grounds. In special education research, investigators use various qualitative methods (Crowley, 1994), such as ethnography (Hammersley \& Atkinson, 1995), case studies (Yin, 1989), participant observation (Spradley, 1980), and cross-case analyses (Miles \& Huberman, 1994).

Faculty of Education, University of Manchester 
In general, in special education research, qualitative and quantitative methods yield different kinds of knowledge and, rather than ruling each other out, these two types of methods can inform, complement, and enrich one another (e.g., Martin \& Sugarman, 1993), and investigators can make an eclectic use of various methods and approaches (e.g., Hopkins, Bollington, \& Hewett, 1989). Stainback and Stainback (1984), in an article in Exceptional Children, compared the relative merits of quantitative and qualitative research. The merits of qualitative research and its particular relevance to special education became clear when investigators realised that the identification of learning and behaviour problems in special education was not a mere mechanical task of finding out which among a series of fixed and standard problem types applied to this or that student. Investigators have contended that problems are always interpreted as such by someone or a number of people, and that it cannot automatically be assumed that a problem is a deficiency within the student, such that our only task is to change or modify the student's behaviour according to some predetermined standard (Heshusius, 1989; Iano, 1989).

Skrtic (1991a) suggests that the problem with theoretical discourse is not pragmatic, because it does not solve the problem of choosing among various theories and disciplinary orientations that have been put forth. Rather, theoretical discourse in special education is crucial because it questions the field's theoretical grounding. However, although there is qualitative research on inclusive education, few studies have mentioned the unique contributions and usefulness of this qualitative research in inclusive education. As the first stage of a longer study, the present article clarifies the contributions that qualitative research has made recently to the philosophy of inclusive education.

\section{Quantitative and Qualitative Research in Special Education}

Kuhn (1970), in his major treatise on scientific revolutions, brought the term "paradigms" into scientific discussion in at least twenty-one different ways, including metaphysical, sociological, and more directly concrete meanings (Heshusius, 1989). Although the names of the paradigms are different, like Lincoln and Guba (1985)'s positivist and naturalist, or Skrtic (1995)'s objectivist and subjectivist, the attitudes toward quantitative and qualitative research methodology can be divided roughly into two different paradigms. I summarised the characteristics associated with qualitative methodology (see Table 1), in order to clarify the nature of qualitative research. Qualitative research is generally done from a discovery orientation, in naturalistic conditions, having an insider's perspective, dynamic reality, and a holistic focus, and resulting in subjective data and valid results (see Table 1).

Barton (1988) contends that the dominant orthodoxy in special education research has led to a narrow interpretation of what counts as legitimate research. This limitation may then restrict the focus of research interest so that the research methods determine the problem investigated, rather than the reverse. Mertins and McLaughlin (1995) suggest that Peck and Furman (1992) explored the importance of qualita- 


\section{Qualitative Research on Inclusive Education}

TABLE 1 General Characteristics of Qualitative and Quantitative Research

\begin{tabular}{|c|c|c|}
\hline Dimensions & Quantitative Paradigm & Qualitative Paradigm \\
\hline Orientation & $\begin{array}{l}\text { Verification-predetermined } \\
\text { hypotheses are investigated }\end{array}$ & $\begin{array}{l}\text { Discovery-theories and hypotheses } \\
\text { are evolved from data as collected }\end{array}$ \\
\hline Data & Objective & Subjective \\
\hline Perspective & Outsider's & Insider's \\
\hline Conditions & Controlled setting & Natural setting \\
\hline Result & Reliable & Valid \\
\hline Focus & Particularistic & Holistic \\
\hline Nature of Reality & Single & Dynamic,multiple \\
\hline Generalisation & $\begin{array}{l}\text { Time- \& context-free generali- } \\
\text { sation is possible }\end{array}$ & $\begin{array}{l}\text { only time- \& context-bound interpreta- } \\
\text { tion is possible }\end{array}$ \\
\hline
\end{tabular}

tive research in special education in terms of recent developments in the philosophy of science. First, qualitative researchers identified the fundamental role of ideology, organisational dynamics, and the social/political process in shaping policy and practice in special education. Second, Peck and Furman (1992) noted the value of constructing the insider's view. They pointed out that qualitative research has enabled the development in special education of professional interventions that are responsive to the cognitive and motivational interpretation of the world held by children, parents, and professionals. For example, definitions of aberrant or inappropriate behaviours can be reframed in terms of their functional meaning for a child. Jacob (1990) also suggests that the social integration of persons with disabilities into mainstream classrooms and the larger society is heavily influenced by how other persons define them and how they define themselves. Last, qualitative methods have led to insights into the cultural values, institutional practices, and interpersonal interactions that influence special education practice. For example, placing and categorising children in special education are subject to these influences, and can be understood only through a process that can look at different levels of social ecology. So, how are these aspects of qualitative research used in inclusive education?

\section{Broader View of Inclusive Education}

Evans and Lunt (2002) noted that over the preceding ten years, there had been a growing impetus worldwide towards full inclusion, stimulated by the Salamanca Statement of 1994 (UNESCO, 1994). The current emphasis on inclusive education is on transforming the mainstream in ways that will increase its capacity for responding to all learners (e.g., Ainscow, 1997). Unlike the notion of integration, the notion of inclusion does not set parameters around particular kinds of putative disability. Rather, it is about a philosophy of acceptance and about providing a framework within which all children, regardless of the provenance of their difficulty at school, can be valued equally, treated with respect, and provided with equal opportunities at 


\section{Y. Isobe}

school (Thomas, 1997). In the UK, for example, a rights agenda was promoted by those who believed that inclusion was a matter of human rights and a liberal society (e.g., Thomas, 1997), or a matter of effectiveness (e.g., Ainscow, 1997). Also, all EU countries now have legislation in place that promotes or requires inclusion.

Recently, definitions of inclusion have been broadened still further (Booth \& Ainscow, 1998). The argument is that the development of schools should be more responsive to the diversity of all learners, rather than concentrating on a group of students categorised as having special needs or disabilities (e.g., Ainscow, 1995; Booth, 1983; Booth, Potts, \& Swann, 1987). In this broader view, inclusion and exclusion are as much about participation and marginalisation in relation to race, class, gender, sexuality, poverty, and unemployment as they are about traditional special education concerns with students categorised as low in attainment, disabled, or behaviourally deviant (Booth \& Ainscow, 1998). In this new view of inclusion, as Corbett (2001) suggests, researchers considered putting inclusion into practice while avoiding the "dump and hope" model from regular education. From this, the emphasis on inclusion in practice became a most valuable starting point for defining the quality of inclusive education. More practical research takes the form of schooland classroom-level modifications (Ainscow, 1995, 1997, 1999) in order to point out patterns and examples of practice that might be instructive to others addressing similar agendas. This would then mean that the energies of the special needs system could be directed not into finding case-by-case approaches to particular configurations of learning characteristics, but rather into identifying and developing broad strategies for responding to commonly occurring difficulties (Dyson \& Millward, 2002). Apart from the traditional deficit model, some authors support a perspective in which difficulties act as prompts to the process of school improvements, and in which special educational needs are seen as a vehicle for improvement of the whole school (e.g., Ainscow \& Hart, 1992).

\section{Classroom Approach and Insider's Perception}

To get close to particular contexts in different schools which have different children, and to improve the quality of inclusive schools, some researchers have reported case studies of schools or classrooms (e.g., Allan, 1999; Dyson \& Millward, 2000; Farrell \& Ainscow, 2002). Methodologically, these studies have tended to use interviews to understand the ways in which stakeholders, such as teachers, pupils, and parents, construct their experiences in schools (Farrell \& Ainscow, 2002). Also as Bassey (1990) has commented, it has started to be recognised that variables such as praise and social conduct can be defined in ways that could apply across different contexts, time, and people. Classrooms are complex places, involving numerous social encounters, the significance of which comes to be understood separately by each participant.

In addition to that, students in inclusive classrooms who are experiencing learning difficulties or disabilities (in the Japanese context, "have intellectual disabil- 


\section{Qualitative Research on Inclusive Education}

ities") have been studied within the broader view of inclusive education, in order to reach out to all learners. For example, collaborative research activities in relation to the development of more inclusive schools (e.g., Ainscow, 1999; Ainscow, Booth, \& Dyson, 2001; Hopkins, Ainscow, \& West, 1994) approach not only students with disabilities but also reach out to all learners, and draw on the views of staff, governors, pupils, parents/caregivers, and other community members, using qualitative data taken from individual voices. Published research, especially in the International Journal of Inclusive Education, is concerned with the diversity of participants who are marginalised because of their race, class, gender, sexuality, or disabilities. In the broader view of inclusive education, qualitative methods are useful especially because they are ideally suited to study individuals' perceptions and beliefs, and the interpretations that define their experience of life. Crowley (1994) also admits the effectiveness of qualitative methods for revealing the perceptions of students, general and special education teachers, administrators, parents or guardians, and others associated with educational programming and overall service delivery. For example, Rose (2001), conducting semi-structured interviews, was able to identify perceptions amongst individual primary school teachers and head teachers that a number of conditions had to be met in order to facilitate a more inclusive education system. On the other hand, Slee (2001) summarised research showing that parents' and pupils' perspectives were welcomed as a counterweight to the common silencing of the voice of students with disabilities and their families.

\section{The School as Organisation}

Turning to the classroom, nowadays, research has showed that teachers' perceptions are that it is not feasible for them to use effective accommodations and desirable adaptations, in light of the other demands on them in the classroom (Gersten \& Woodward, 1990; Klingner \& Vaughn, 1999). Some researchers (Ainscow, 1991; Skrtic, 1991a, b, c; Stainback \& Stainback, 1990; Villa, Thousand, Stainback, \& Stainback, 1992) regard this as an organisational paradigm, in view of the important claims made by the adherents of this paradigm for the opportunities that it is alleged to offer for rethinking special needs. Like other social institutions, teachers are influenced by perceptions of socioeconomic status, race, language, and gender. This being the case, researchers say that it is essential to question how such perceptions may influence classroom interactions and classroom dynamics (Clark, Dyson, \& Millward, 1998).

To understand the meaning of their actions (including "voices"), it is said that one cannot ignore context, that is, a culturally and historically situated place and time, a specific here and now (Graue \& Walsh, 1998). Qualitative methods permit context-based analysis that can uncover the unique overt and covert workings of a particular context (Crowley, 1994).

Although Peters (1993) contends that people with disabilities and also professionals have socially constructed historically mediated categories of experience, others 
argue that it is important to remember that schools, like other institutions, are influenced by people's perceptions of socioeconomic status, race, language, and gender. This being the case, it is essential to question how perceptions influence classroom interactions.

These trends led to the growing amount of research conducted by teachers as researchers, or collaborative action research, carried out in schools (e.g., Ainscow \& Brown, 1999). The goal of this research is not to propose recipes that can be applied universally, but rather to suggest ingredients that might be worthy of further consideration within particular contexts. This stance with respect to generalisation and multiple realities in different contexts in different organisations has often been supported by qualitative research as well (e.g., Lincoln, 1990).

Skrtic (e.g., 1991a, b, c) also stresses that special education is necessary to shift from a narrow and mechanistic view of teaching to one that is broader in scope and takes into account wider contextual factors. Some agree that careful analysis of differences in perspective, context, and meanings enhances rather than reduces the contribution that an examination of unfamiliar contexts can make to local practice, although it may invalidate attempts at simple imitation (Fuller \& Clarke, 1994). It is vital to evaluate institutional practices, the routines and rituals of classroom patterns, and the cultures within schools (e.g., Corbett, 2001).

\section{The Student's Viewpoint and Future Research}

Dyson and Millward (2000) note that, in the UK, it has been claimed that special education professionals act in their own, rather than their clients' interests (see also Tomlinson, 1982; 1985), that special education is a mechanism whereby some social groups exercise power over others (see, e.g., Barton, 1988), that special needs and disabilities are not characteristics of individuals that can be observed but rather the outcomes of a process of social construction and creation (Abberley, 1987; Oliver, $1988 ; 1990)$, and that there is need to set the voice of people with disabilities in dialogical opposition to the monologue of the professional voice (Clough \& Barton, 1995; 1998).

Within classroom research in the inclusive setting, in addition to teachers' perceptions and their use of effective accommodations and desirable adaptations, the perspectives especially of students about the integration of students with learning difficulties have recently been of increasing interest. According to Klingner and Vaughn (1999), there are three possible reasons for this change. First, students' views about instructional practices in inclusive settings are likely to be communicated directly to teachers and to influence them and their practice. Second, allowing the expression of students' views on appropriate practices to implement potentially increases students' involvement, understanding, and motivation to learn. Third, if we consider students' responsibility for their own learning an essential factor in accounting for their learning (Ericson \& Ellett, 1990), then students' perceptions of teaching practices should be identified. 


\section{Qualitative Research on Inclusive Education}

Since the definition of inclusive education discussed in the present article addresses the needs of all children, the scope of the studies reviewed should not be restricted to any particular children with or without disabilities. Actually, research in the area of pupil involvement (Cooper, 1993) has indicated clear advantages to be gained through high levels of pupil participation. However, it was reported that this was a group of children with moderate and severe disabilities who had been routinely segregated from contact in general education classrooms with children without disabilities (Meyer \& Putnam, 1988). Allan (1999) also notes that the voice of the child has been absent from most accounts of special education, silenced by professional discourses, which are concerned with matters of placement and practice. Similarly some researchers have contended that the voices of children with disabilities have been ignored (Lewis, 1995; Lynas, 1986; Sheldon, 1991).

Especially, little specific research has been done with children who have severe or profound disabilities, although many studies have shown that children with even very profound disabilities have feelings and ideas to express (Detheridge, 2000). Detheridge (2000) mentioned some possible reasons for this. First, these children are likely to have significant communication difficulties, may be non-speaking, and are likely to have other disabilities which affect their ability to respond to stimuli in their environment. Second, the particular difficulties and unique communication patterns of these children challenge the researcher in terms of validity and reliability of data. The means of communication may be complex, unusual, and, through aiming to simplify, open to misinterpretation. So although qualitative methods give us access to the human voice, new methods will have to be explored in order for researchers to be able to understand the feelings of pupils with severe and profound disabilities.

Actually, some reviews of the research literature contain some useful summaries of the skills needed for or strategies in researching children's perceptions, and describe other ways of enhancing validity. For example, Backett and Alexander (1991) suggest that structured activities such as drawing, writing, reading, sorting cards, and talking are especially useful for helping very young children focus on a research topic. In the special education area, Lewis (1995; 2002) used drawings by children with disabilities in order to communicate about the integrated situation in schools. Mauthner (1997) explored methods such as interviews and paper-and-pencil instruments which may be more suitable for older children. Participant-observation and small group discussions are particularly suitable techniques with five- to six-yearolds (Mauthner, 1997). Small groups are ideal with same-age groups of children (peer groups), rather than with groups of children at mixed ages (sibling groups). Small group discussions allow children to set their own agendas, and the research topic can be woven into children's conversations about their daily lives and social world. The "draw and write technique" and structured activities can be integrated effectively into group discussions and interviews in order to provide a focus for children.

However, it should be noted that this previous research has two weaknesses. First, the reasons for those studies' use of non-verbal data was to strengthen interview data, not in order to focus on the use of non-verbal devices. This means that 
qualitative research has not succeeded in approaching children who have severe or profound disabilities and who might use different communication patterns from children without disabilities. Second, although some studies (e.g., Lewis, 1995) stress the importance of studying children in context, different methods were not used with different children, even though the children might have had particular difficulties and unique communication patterns.

Qualitative methods provide varied ways to gather information and understand the meanings of children's communications, in order to discover children's views at school. However, there also is a need to explore methods or strategies for gathering the views toward inclusive schools of children who have severe or profound disabilities.

\section{Conclusion}

Special education professionals have been concerned about a variety of issues well suited to the use of qualitative research in inclusive education. During the past two decades, researchers have increasingly used qualitative research on putting inclusion into practice and in order to capture human voices in schools and classrooms where insiders such as pupils spend most of their time, and in situations in which context-based perceptions are always changing. Within classroom research in inclusive settings, however, methods or strategies should be explored that would enable researchers to gather views about inclusive schools of children who have severe or profound disabilities.

\section{References}

Abberley, P. (1987) The concept of oppression and the development of a social theory of disability. Disability, Handicap and Society, 2(1), 5-19.

Ainscow, M. (Ed.) (1991) Effective schools for all. Fulton, London.

Ainscow, M. (1995) Education for all: Making it happen. Support for Learning, 10(4), 147-55.

Ainscow, M. (1997) Towards inclusive schooling. British Journal of Special Education, 24(1), 3-6.

Ainscow, M. (1999) Understanding the development of inclusive schools. Falmer Press, London. Ainscow, M. \& Brown, D. (Eds.) (1999) Guidance on improving teaching. Falmer Press, London. Ainscow, M., Booth, T., \& Dyson, A. (2001) Understanding and developing inclusive practices in schools. Paper presented at the American Educational Research Association Conference, Seattle, Washington, April.

Ainscow, M. \& Hart, S. (1992) Moving practice forward. Support for Learning, 7(3), 115-120. Allan, J. (1999) Actively seeking inclusion. Falmer Press, London.

Backett, K. \& Alexander, H. (1991) Talking to young children about health: Method and findings. Health Education Journal, 50(1), 34-38.

Barton, L. (Ed.) (1988) The politics of special educational needs. Falmer Press, London.

Bassey, M. (1990) Crocodiles eat children. CARN Bulletin, No.4. Cambridge Institute of 
Education, Cambridge, England.

Booth, T. (1983) Integrating special education. In T. Booth \& P. Potts (Eds.), Integrating special education. Blackwell, Oxford, 1-27.

Booth, T. \& Ainscow, M. (Eds.) (1998) From them to us: An international study of inclusion in education. Routledge, London.

Booth, T., Potts, P., \& Swann, W. (Eds.) (1987) Curricula for all: Preventing difficulties in learning. Blackwell, Oxford.

Clark, C., Dyson, A., \& Millward, A. (Eds.) (1998) Theorising special education. Routledge Falmer, London.

Clough, P. \& Barton, L. (Eds.) (1995) Making difficulties: Research and the construction of SEN. Paul Chapman, London.

Clough, P. \& Barton, L. (Eds.) (1998) Articulating with difficulty: Research voices in inclusive education. Paul Chapman Publishing, London.

Cooper, P. (1993) Effective schools for disaffected students. Routledge, London.

Corbett, J. (2001) Supporting inclusive education: A connective pedagogy. Routledge Falmer, London.

Crowley, E. P. (1994) Using qualitative methods in special education research. Exceptionality, 5(2), 55-69.

Detheridge, T. (2000) Research involving children with severe learning difficulties. In A. Lewis \& G. Linsay (Eds.), Researching children's perspectives. Open University Press, Buckingham/Philadelphia, 112-121.

Dyson, A. \& Millward, A. (2000) Schools and special needs. Paul Chapman, London.

Dyson, A. \& Millward, A (2002) Looking them in the eyes: Is rational provision for students "with special educational needs" really possible? In P. Farrell \& M. Ainscow (Eds.), Making special education inclusive: From research to practice. Taylor \& Francis, London, 1324.

Ericson, D. P. \& Ellett, F. J. (1990) What can research on teacher thinking contribute to teacher preparation? A second opinion. Educational Researcher, 19(9), 3-10.

Evans, J. \& Lunt, I. (2002) Inclusive education: Are there limits? European Journal of Special Needs Education, 17(1), 1-14.

Farrell, P. \& Ainscow, M. (Eds.) (2002) Making special education inclusive: From research to practice. David Fulton Publishers, London.

Ferguson, P. M., Ferguson, D. L., \& Taylor, S. J. (Eds.) (1992) Interpreting disability: A qualitative reader. Teachers College Press, NY.

Fosnot, C. T. (1989) Inquiring teachers, inquiring learners: A constructivist approach for teaching. Teachers College Press, NY.

Fuller, B. \& Clark, P. (1994) Raising school effects while ignoring culture? Local conditions and the influence of classroom tools, rules and pedagogy. Review of Educational Research, 64(1), 119-157.

Gersten, R. \& Woodward, J. (1990) Rethinking the regular education initiative: Focus on the classroom teacher. Remedial and Special Education, 11(3), 7-16.

Graue, M. \& Walsh, D. (1998) Studying children in context: Theories, methods, and ethics. Sage, Thousand Oaks, California.

Guba, E. G. \& Lincoln, Y. S. (1989) Fourth generation evaluation. Sage, Thousand Oaks, California. 
Hammersley, M. \& Atkinson, P. (1995) Ethnography: Principles in practice (2nd ed.). Routledge, London.

Heshusius, L. (1982) At the heart of the advocacy dilemma: A mechanistic worldview. Exceptional Children, 49, 6-11.

Heshusius, L. (1989) The Newtonian mechanistic paradigm, special education, and contours of alternatives: An overview. Journal of Learning Disabilities, 22, 403-415.

Hopkins, D., Ainscow, M., \& West, M. (1994) School improvement in an era of change. Cassell, London.

Hopkins, D., Bollington, R., \& Hewett, D. (1989) Growing up with qualitative research and evaluation. Evaluation and Research in Education, 2(3), 61-80.

Iano, R. P. (1989) Comments related to Professor Heshusius' application of paradigm change to special education. Journal of Learning Disabilities, 22, 416-417.

Jacob, E. (1990) Alternative approaches for studying naturally occurring human behavior and thought in special educational research. Journal of Special Education, 24, 195-211.

Klingner, J. K. \& Vaughn, S. (1999) Students' perceptions of instruction in inclusion classrooms: Implications for students with learning disabilities. Exceptional Children, 66, 23-37.

Kuhn, T. S. (1970) The structure of scientific revolutions. University of Chicago Press, Chicago, Illinois.

Lewis, A. (1995) Children's understanding of disability. Routledge, London.

Lewis, A. (2002) The development of children's ideas about others' difficulties in learning. British Journal of Special Education, 29(2), 59-63.

Lincoln, Y. S. \& Guba, E.G. (1985) Naturalistic inquiry. Sage, Beverly Hills, Galifornia.

Lincoln, Y. S. (1990) The making of a constructivist: A remembrance of transformations past. In E. G. Guba (Ed.), The paradigm dialog. Sage, Thousand Oaks, California, 6787.

Lynas, W. (1986) Pupils' attitudes to integration. British Journal of Special Education, 13(1), 31-33.

Martin, J. \& Sugarman, J. (1993) Beyond methodolatry: Two conceptions of relations between theory and research in research on teaching. Educational Researcher, 22(8), 17 24.

Mauthner, M. (1997) Methodological aspects of collecting data from children: Lessons from three research projects. Children and Society, 11, 16-28.

Mertins, D. M. \& McLaughlin, J. A. (1995) Research methods in special education: Applied social research methods series: Vol. 37. Sage Publications, London.

Meyer, L. H. \& Putnam, J. (1988) Social integration. In V. B. Van Hasselt, P. S. Strain, \& M. Hersen (Eds.), Handbook of developmental and physical disabilities. Pergamon Press, Elmsford, NY, 107-133.

Miles, M. B. \& Huberman, A. M. (1994) Qualitative data analysis: An expanded sourcebook (2nd ed.). Sage, Thousand Oaks, California.

Oliver, M. (1988) The social and political context of educational policy: The case of special needs. In L. Barton (Ed.), The politics of special educational needs. Falmer, London, 13-31.

Oliver, M. (1990) The politics of disablement. Macmillan, London.

Peck, C. A. (1991). Linking values and science in social policy decisions affecting citizens with severe disabilities. In L. H. Meyer, C. A. Peck, \& L. Brown (Eds.), Critical issues 


\section{Qualitative Research on Inclusive Education}

in the lives of people with severe disabilities, Paul H. Brookes, Baltimore, 1-15.

Peck, G. A. \& Furman, G. C. (1992) Qualitative research in special education: An evaluative review. In R. Gaylord-Ross (Ed.), Issues and research in special education (Vol. 2). Teachers College Press, NY, 1-42.

Peters, S. J. (Ed.) (1993) Education and disability in cross-cultural perspective. Garland Publishing, NY.

Rose, R. (2001) Primary school teacher perceptions of the conditions required to include pupils with special educational needs. Educational Review, 53, 147-156.

Sheldon, D. (1991) How was it for you? Pupils', parents' and teachers' perspectives on integration. British Journal of Special Education, 18(3), 107-110.

Skrtic, T. M. (1986) The crisis in special education knowledge: A perspective on perspective. Focus on Exceptional Children, 18(7), 1-16.

Skrtic, T. M. (1991a) Behind special education: A critical analysis of professional culture and school organization. Love Publishing, Denver, Colorado.

Skrtic, T. M. (1991b) Students with special educational needs: Artifacts of the traditional curriculum. In M. Ainscow (Ed.), Effective schools for all. David Fulton, London, 20-42.

Skrtic, T. M. (1991c) The special education paradox: Equity as the way to excellence. Harvard Educational Review, 61, 148-206.

Skrtic, T. M. (Ed.) (1995) Disability and democracy: Reconstructing (special) education for postmodernity. Teachers College Press, NY.

Slee, R. (2001) "Inclusion in practice": Does practice make perfect? Educational Review, 53, $113-123$.

Spradley, J. P. (1980) Participant observation. Holt, Rinehart \& Winston, NY.

Stainback, S. \& Stainback, W. (1984) Broadening the research perspective in special education. Exceptional Children, 50, 400-408.

Stainback, W. \& Stainback, S. (1990) Support networks for inclusive schooling. Paul H. Brookes, Baltimore, Maryland.

Taylor, S. J. (1988) Preface to "Generations of hope." Journal of The Association for Persons with Severe Handicaps, 13, 175-176.

Thomas, G. (1997) Inclusive schools for an inclusive society. British Journal of Special Education, 24, 251-263.

Tomlinson, S. (1982) A sociology of special education. Routledge and Kegan Paul, London.

Tomlinson, S. (1985) The expansion of special education. Oxford Review of Education, 11, $157-165$.

UNESCO (1994) The Salamanca Statement and framework on special needs education. Author, Paris.

Villa, R. A., Thousand, J. S., Stainback, W., \& Stainback, S. (Eds.) (1992) Restructuring for caring and effective education: An administrative guide to creating heterogeneous schools. Paul $\mathrm{H}$. Brookes, Baltimore, Maryland.

Yin, R. K. (1989) Case study research: Design and methods (2nd ed.). Sage, Newbury Park, California.

- Received October 14, 2003; Accepted February 7, 2004- 